\title{
PAVIMENTO Y PATRIMONIO EN LAS CIUDADES HISTÓRICAS. REFLEXIONES A PROPÓSITO DE UNA INTERVENCIÓN SINGULAR EN CÓRDOBA (ESPAÑA)
}

\author{
Martín Torres Márquez \\ María Luisa Ramírez López \\ Rafael Garzón García ${ }^{1}$ \\ Departamento de Geografía y Ciencias del Territorio. Universidad de Córdoba \\ martin.torres@uco.es, mluisa.ramirez@uco.es, rafael.garzon@uco.es
}

\section{RESUMEN}

Uno de los aspectos menos tratados en los estudios paisajísticos de la ciudad y sus implicaciones en la construcción de la imagen patrimonial urbana, especialmente de sus centros históricos, es el pavimento. Las vías públicas configuran las «arterias» de una ciudad, y son los itinerarios que permiten acceder a los lugares más singulares. El pavimento influye en la configuración de los paisajes, a la par que, en las ciudades históricas, es parte de su valor patrimonial, capaz de renovar la imagen cultural de una ciudad, dinamizar la economía o servir de instrumento para plasmar hechos singulares del pasado.

Palabras clave: pavimento urbano, paisaje urbano, ciudad histórica, patrimonio, Córdoba.

\section{ABSTRACT}

One of the least discussed aspects of the cities landscape study is the pavement of the public thoroughfare. The streets and squares make up the «arterial» network of the city. The pavement, beyond its mechanical function, has an obvious influence in the configuration of

Fecha de recepción: octubre 2012.

Fecha de aceptación: julio 2013.

1 Pertenecen al Grupo de Investigación Estudios de Geografía (HUM-247) de la Universidad de Córdoba y son miembros del proyecto Dinámicas funcionales y ordenación de los espacios del Sistema del Patrimonio Territorial andaluz: análisis en Andalucía Occidental, financiado por el Ministerio de Ciencia e Innovación de España y cuyo investigador principal es el Prof. Dr. José Naranjo Ramírez (Universidad de Córdoba). Miembros igualmente del proyecto Archivo documental de percepciones y representaciones de paisajes andaluces, cuyo investigador principal es el Prof. Dr. Juan Francisco Ojeda Rivera (Universidad Pablo de Olavide, Sevilla). 
the landscape; at the same time that it is a part of the heritage value, capable of renovating the cultural picture of a city, boosting the economy or even being used as a tool to show the main elements of the historical cities. One example of this importance, relating to the city of Cordoba (Spain), is presented in this work.

Keywords: urban pavement, urban landscape, historic city, heritage, Cordoba.

Uno de los elementos que constituyen la ciudad como expresión física de la ordenación del territorio, obviado con frecuencia por los estudios geográficos o por la investigación del paisaje urbano, es la pavimentación de la vía pública, las superficies externas y artificiales que cubren las calles, plazas, zonas verdes, etc. Este aspecto del paisaje urbano, esencial para las funciones modernas de la ciudad, influye en la construcción estética y en la imagen de la ciudad antigua y contemporánea. Ha sido, a nuestro entender, un innegable elemento y signo de la identidad de lo urbano frente a lo rural y, por añadidura, adquiere valores de identidad y singularidad que sostienen en no pocas ocasiones la imagen patrimonial y turística de algunos destinos históricos. No podemos negar que la pavimentación de la vía pública es una variable de la ciudad que condiciona y singulariza una parte destacada del espacio público y, por tanto, ayuda a fijar las funciones y la imagen de dicho espacio urbano. La vía pública y, al mismo tiempo, su cubierta exterior o pavimento, tiene un papel notorio en la estructura urbana, en el «lenguaje» de la ciudad, en su calidad ambiental y estética, así como en su propia construcción simbólica y paisajística, pues es el medio que vivimos y que perdura en la memoria como parte de los lugares (Jacobs, 1996; Escobar Ángel, 2000; Herce Vallejo y Miró Farrerons, 2002).

Las páginas que siguen registran los resultados de un estudio de caso que, en última instancia, pretende enfatizar el papel de la vía pública, la pavimentación y las reformas urbanas en la percepción patrimonial, la accesibilidad y la comprensión de los centros históricos como espacios rescatados del pasado y reinventados para la demanda peatonal y turística.

\section{PAVIMENTO DE LA VÍA PÚBLICA Y CONSTRUCCIÓN DE LA CIUDAD}

El origen de la ciudad como territorio ordenado respecto al medio natural y rural limítrofe representa una geometrización de las variables originales, una racionalización sustentada en la construcción de elementos artificiales que coadyuvan de forma interesada al desarrollo de la ciudad como recipiente humano y con múltiples funciones e intereses privados y colectivos. Las ciudades se han construido y modelado siempre según los criterios urbanísticos y las necesidades de cada época, y algunas aún conservan, a pesar de los cambios, esas páginas que testimonian el paso de los siglos (Morris, 1998).

Desde el imperio hitita ya existe constancia del desarrollo de pavimentos y firmes que permitían o mejoraban el tránsito de ciertas vías principales que atravesaban el territorio (Rama Labrador, 2005 y 2006). Sin embargo, al menos en el contexto geohistórico europeo²,

2 Fuera del ámbito europeo tenemos constancia de un uso desigual de la pavimentación de viales urbanos o interurbanos en el pasado histórico. Al respecto, por ejemplo, cabe señalar la construcción de las vías procesionales del pueblo maya, conocidas como «saches»; o la pavimentación de ciertas arterias en la cultura azteca o inca. 
parece cierto que el desarrollo de la pavimentación coincidió con el período de dominación romana. Sin ahondar en detalles técnicos relacionados con estas pavimentaciones romanas, pues no es este el fin del presente trabajo y existen suficientes estudios al respecto (Moreno Gallo, 2004, 2008, 2010; Alba, Moreno Gallo y Rodríguez, 2004; etc.), resulta evidente la herencia que este proceder urbanístico habría de transmitir en el desarrollo de la ciudad futura, hasta el punto que la ciudad europea medieval habrá de conservar, entre sus singularidades físicas y funcionales, el empleo de calles y plazas principales pavimentadas. Éstas, aún con un acabado menos noble que los clásicos ejes de la «urbs quadrata», seguirán constituyendo buena parte de la identidad paisajística de la ciudad tras la caída del Imperio Romano y hasta bien entrada la Edad Moderna.

Desmembrado el Imperio, tras la consecuente atomización política y administrativa del territorio, asistimos al desarrollo de ciudades autónomas y la revitalización de la administración local mediante el progreso de múltiples fórmulas para la gestión de los recursos próximos, el cobro de impuestos, la defensa de la ciudad, etc. Con tales cambios surgen nuevas necesidades políticas, sociales, económicas y urbanas, acompañadas de una creciente sacralización de la urbe y envueltas en un escenario definido por la estrechez económica, la guerra o incluso las frecuentes crisis de subsistencia. No faltan ejemplos en este sentido de ciudades que languidecieron hasta llegar a su práctica desaparición; así como otras conocieron una insospechada revitalización demográfica y constructiva de la mano de la economía gremial, del comercio o incluso gracias al desarrollo de las peregrinaciones (Passini, 1984). Dicho con otras palabras, son muy diversas las circunstancias territoriales que cabe señalar para este convulso y heterogéneo período histórico en el contexto europeo, por lo que también habrán de ser múltiples las manifestaciones y los paisajes urbanos que cabe identificar (Heers, 1990; Arízaga Bolumburu, 1990 y 1993).

Como resultado de las circunstancias mencionadas la estructura de las ciudades sufre cambios significativos que afectan de manera evidente a la función, disposición y pavimentado de la vía pública. El medio público de la urbe medieval, constreñido con frecuencia por la topografía o por los recintos amurallados, reduce sus dimensiones y se adapta a las nuevas circunstancias. Buena parte de los recursos materiales, económicos y humanos se destinan al cuidado y conservación de las murallas o incluso a la ejecución de los grandes edificios religiosos que habrán de ser símbolos de sus respectivas ciudades, mientras los espacios públicos internos y sus firmes pierden buena parte de la nobleza formal y funcional del período clásico. A pesar de ello resulta frecuente, sobre todo en las grandes vías y plazas de las ciudades medievales más conspicuas, junto a edificios civiles o religiosos, en las travesías y «calles reales», la persistencia de la pavimentación artificial, bien con losas de piedra más o menos concertadas o con el empleo de los característicos empedrados, generalmente de cantos rodados de cuarcitas y otras rocas resistentes que ofrecían adecuadas propiedades para el tránsito de caballerías, ganado, peatones y modestos carros.

Desde el casco antiguo de Tallin (Estonia), hasta el callejero histórico de Córdoba, pasando por el transformado recinto medieval de Carcassonne (Francia), es manifiesta la existencia de una evidente mercantilización de esos pavimentos antiguos, unas veces originales y otras recreados o reinterpretados, pero que, sin duda, suponen un giro en la funcionalidad de las ciudades, su movilidad y la imagen, en particular, de los centros históricos, que ahora ofrecen indudables posibilidades económicas de la mano de la gestión cultural y 
el consumo turístico (Campesino Fernández, 2001). Quizás los visitantes no acuden a esas ciudades atraídos por la presencia del empedrado medieval, pero parte, no poca, de la imagen histórica y de las estampas paisajísticas que sirven de reclamo al visitante está alojada en esos pavimentos pretéritos, pues ellos son el mosaico del entramado de las calles zigzagueantes, y constituyen la «cota cero» de un espacio arquitectónico que sólo puede conservar su salud cultural, estética y simbólica si conserva una adecuada armonía con el pavimento que constituye el plano horizontal sobre el que se levanta ${ }^{3}$.

Según los estudios de Rama Labrador (2006), a finales del siglo XVIII las ciudades españolas más importantes, entre otras del contexto europeo, conocieron la introducción de nuevos pavimentos, así como de modelos, técnicas y materiales más diversificados que en tiempos pasados. El tradicional y casi constante empedrado medieval, que sólo presentaba variantes leves respecto a la disponibilidad de la materia prima local, conoció la irrupción de nuevas fórmulas de pavimentación. Éstas mejoraban sustancialmente la limpieza e higienización de la vía pública, facilitaban el desplazamiento y giro de los nuevos carruajes, ofrecían un sellado más eficaz y mejoraban sensiblemente el aspecto de plazas y calles principales, así como las cercanías de lugares que se abrían y proporcionaban perspectivas a templos y palacios. No podemos olvidar el papel de la vía pública como escaparate de la vanidad y el poder, especialmente en una sociedad urbana donde los grupos privilegiados eran los que estimulaban buena parte de las reformas y cambios del paisaje urbano, de su arquitectura, sus bulevares y sus paseos.

Los pavimentos que se introdujeron en las ciudades españolas de cierta relevancia económica y política fueron los que seguidamente citamos, pues las más modestas o menos dinámicas siguieron conservando y remozando el tradicional empedrado, con la inserción de ciertas mejoras, hasta mediados del siglo XX: pavimento de adoquín «rodeno»; pavimento de mosaico con adoquín formado por bloques de pórfido; pavimento de hormigón blindado e inserción de lajas de rocas variopintas; y, en cuarto lugar, el «firme blanco», consistente en una capa de unos $20 \mathrm{~cm}$ de espesor integrada por un lecho de piedra machacada y recebo con árido de machaqueo o tierra seleccionada (Rama Labrador, 2006).

El desarrollo de la Revolución Industrial y la aplicación de nuevas técnicas y materiales provocaron un sustancial cambio en aquellas ciudades que se beneficiaron de tales innovaciones. A principios del siglo XIX se constata el empleo del alquitrán en riego para la pavimentación de ciertas calles de las ciudades pioneras en el proceso industrializador. El uso del alquitrán no era novedoso. Muy al contrario, existe constancia cierta de que ya la ciudad de Bagdad tuvo sus calles cubiertas de alquitrán en el siglo VIII (Ajram, 1992), e incluso el uso del asfalto, material de aspecto similar pero diferente al alquitrán, está arqueológicamente atestiguado en la antigua Mesopotamia, el Indo y Egipto (Rama Labrador, 2006). Sin embargo hasta el siglo XIX no cabe hacer referencia a un empleo masivo ni industrial del alquitrán como materia de pavimentación de viales urbanos o interurbanos, e incluso

3 Una iniciativa coordinada de recuperación de los pavimentos tradicionales en los núcleos rurales andaluces es el programa «Cal y Canto» promovido a iniciativa de la Diputación Provincial de Málaga, el Grupo de Desarrollo y la Mancomunidad de municipios de la Sierra de las Nieves (Málaga). En este proyecto, entre otras acciones, se incluyen la recuperación, creando nuevas estampas urbanas y referentes simbólicos sobre un ideario rural/urbano, de antiguas vías históricas de localidades malagueñas como Alozaina, Casarabonela, El Burgo, Guaro, Istán, Monda, Ojén, Tolox o Yunquera. 
para España su uso masivo será tardío debido a la mala calidad de la producción nacional y a las limitaciones existentes a la importación hasta casi mediados del siglo XX (Llamazares Gómez, 1963; Diego García, 1996: 39; Alarcón Ibarra, 2003).

A pesar de que en el siglo XIX ya se comienza a utilizar el alquitrán en las vías públicas, no será hasta entrado el XX cuando se produzca la verdadera expansión del uso de esta sustancia (Correyo Ruiz y Cal, 2008: 106). El creciente uso de las mezclas bituminosas, tanto en carreteras como en viales urbanos, se hace aún más patente a partir de la II Guerra Mundial. El resultado habrá de ser una expansión de los viales ennegrecidos mediante derivados del petróleo, así como una irrefrenable difusión del tráfico rodado impulsado por los motores de explosión. Históricamente las calles, junto a funciones menos evidentes, habían tenido un doble cometido: por un lado, la función de la movilidad, pues la calle facilitaba el desplazamiento de las personas, de los animales domésticos y de los carros; y, por otro, era el lugar donde se desarrollaba gran parte de la vida pública de la urbe, ya que era el medio propicio para estar, trabajar, comerciar, reunirse, establecer relaciones sociales o incluso celebrar fiestas y espectáculos.

Empero, la aparición del automóvil y el desarrollo de la pavimentación con alquitrán supone una nueva e importante revolución para las ciudades y consecuentemente para la vida urbana, tanto en cuanto a su diseño y forma, como en lo que respecta a sus dimensiones, trazado y funciones (Hall, 1996). De los dos cometidos referidos empieza a tener primacía uno de ellos sobre el otro; y la calle pasa a ser preeminentemente el área para el transporte y el desplazamiento de la circulación de vehículos motorizados, perdiendo su carácter de lugar abierto destinado al encuentro social entre los habitantes de la ciudad. Gran parte de la sección de la vía se reserva al transporte de los vehículos, exigiendo la masiva introducción del alquitrán u otros pavimentos resistentes y cómodos para la rodadura; mientras que sólo unas estrechas franjas, las aceras, se reservan al tránsito peatonal. Las relaciones entre las personas, que antes se realizaba en la vía pública, siguen existiendo en la ciudad, pero ahora es en el interior de los edificios, en los escasos paseos y bulevares, o en los pocos espacios ajardinados donde la comunidad se divierte, charla y se conoce. El rápido desarrollo urbano, la urbanización de la periferia de las ciudades y el gran crecimiento del tráfico automovilístico caracterizaron el periodo inmediatamente posterior a la II Guerra Mundial, especialmente en Europa.

El crecimiento del parque automovilístico, sobre todo en los años setenta y ochenta, provocará que las calles se adapten de forma estándar al automóvil, desapareciendo paseos y bulevares, y estrechando las aceras para mejorar la circulación y el aparcamiento de los vehículos. De manera paralela, aunque con ritmos diferentes según las circunstancias de cada ciudad, se abandonan los antiguos pavimentos de piedra o los adoquinados tradicionales, pues resultaban incómodos y ruidosos para los automóviles, introduciendo nuevos pavimentos más cómodos, sencillos y rápidos de construir. Entre los pavimentos urbanos que comenzaron a ennegrecer el suelo de la ciudad, especialmente en los nuevos ensanches, pero también en muchas de las calles de sus cascos históricos, cabe señalar por su frecuencia dos tipos: el pavimento de losetas de asfalto comprimido, que cubrió buena parte de las grandes vías españolas desde prácticamente los años veinte del siglo XX (Compañía Peninsular de Asfaltos, 1930); y el pavimento «Warren», llamado así por el nombre de la empresa que lo comercializaba.

En la actualidad, especialmente a partir del último tercio del siglo XX, se hace patente la amplia oferta existente en materia de pavimentación, e incluso los notables cambios acaeci- 
dos en aspectos como la planificación y el diseño de la vía pública. Materiales antiguos, nuevos tratamientos y técnicas han incrementado el número de superficies posibles, así como sus acabados, resistencias, valores estéticos o incluso sus facultades físicas y ambientales. Ahora, por ejemplo, cabe citar la existencia de nuevas fórmulas como el uso de microaglomerados, pavimentos drenantes, fonoabsorbentes, etc. Al mismo tiempo, no es menos cierto que a estas novedades se suma también la revisión de algunos de los principios que habían alterado la función social y la calidad ambiental de la vía pública en beneficio del tráfico, cuestión que había sido especialmente grave en el caso de los antiguos cascos históricos (Herce Vallejo, 2009). Sin ir más lejos, en el Congreso Mundial de Carreteras de Marrakech de 1991 el Comité de la Ciudad presentó un informe que revisaba de manera sensible la visión de la vía pública en la urbe, pues recomendaba una recuperación de sus funciones sociales, ecológicas y económicas; funciones que se habían perdido en beneficio del tráfico rodado, pues los planificadores habían cedido desmedidamente ante los intereses de una sociedad cada vez más esclavizada por el uso del vehículo particular, por la necesidad de utilizarlo, moverse con él o estacionarlo (ELSAN-PACSA, 2003: 9; Francalacci Silva, 2010).

\section{PAVIMENTOS Y CONSTRUCCIÓN DEL PAISAJE DE LA CIUDAD}

Creemos apropiado iniciar este apartado ofreciendo unas breves consideraciones, desde la perspectiva geográfica, respecto al complejo y atractivo concepto de paisaje. Este concepto, de creciente éxito académico y científico, compendia la imagen real y también simbólica de un área o territorio determinado, ya sea rural, urbano, acuático, forestal, etc. Es, en último extremo, el resultado de la acción combinada de los múltiples componentes físico-naturales y antrópicos que participan en su composición y evolución. En todo paisaje se hallan elementos tangibles que podemos percibir a través de los sentidos; y también existen otros elementos o procesos menos perceptibles o incluso ocultos a nuestras percepciones. Es el paisaje la función de realidades y procesos fenológicos y también de elementos y procesos criptológicos (González Bernáldez, 1981). Unos y otros adquieren protagonismos diversos en las interrelaciones que los condicionan entre sí, dando como resultado lo que denominamos paisaje geográfico. El paisaje urbano es generalmente aquel que expresa un mayor grado de transformación y artificialidad de los recursos y condiciones naturales. Es, ese paisaje urbano, un fenómeno físico y también simbólico que cambia permanentemente a través de la historia y en consonancia con las mudanzas políticas, económicas, culturales y sociales de la comunidad que los habita; pero también se transforma en virtud de lo que la población visitante demanda de él (Brandis García y Río Lafuente, 2006; Brandis García, 2008 y 2010).

Tales factores, entre otros, son los que explican los cambios y transformaciones urbanas y el modelado de sus paisajes; paisajes que se distinguen de los rurales u otros por el elevado grado de artificialización de sus componentes. Es esa configuración y esos atributos y factores del paisaje urbano los que explican la heterogeneidad de lo urbano a escala mundial, así como su desigual expresión en el tiempo, el espacio y la forma (Brandis García y Canosa, 2009). Y en todos esos cambios, elementos, relaciones y símbolos del paisaje urbano no podemos excluir la importancia del pavimento de la vía pública, más aún cuando facilita o condiciona la transitabilidad y la accesibilidad de la ciudad; contribuye en la configuración 
estructural de la urbe; y cuando, por lo general, es uno de los componentes urbanos más perceptibles a la hora de construir la imagen de una ciudad y sus atractivos.

El ser humano tiene la facultad de crear una idea, una imagen, del espacio en su conjunto. Cuenta con la posibilidad de, mediante la percepción sensitiva y la participación de los recuerdos y emociones, construir la imagen global de aquello que le rodea y de su propia identidad en dicho contexto. Este proceso se sustenta en la capacidad de simultanear y digerir intelectualmente lo que el presente ofrece, activando también la colaboración de los recuerdos y emociones. A este fin coadyuvan, según Cullen, tres caminos distintos y colaborativos: la óptica, el lugar y el contenido. Mediante el camino de la óptica, como principal percepción humana, los escenarios urbanos nos son revelados al transitar por ellos, ofreciendo una visión seriada de estampas, escenas, rincones y de los elementos que los integran. El camino del lugar es la capacidad humana de procesar todas las percepciones que recibe, no sólo visuales, y mediante ellas relacionarse con su entorno, bien con el propósito de sobrevivir, desarrollarse o sencillamente deleitarse. Esta vía de conexión con el paisaje acentúa la necesidad de planificar y ordenar la ciudad o cualquier otro paisaje desde el punto de vista de una persona en movimiento, tanto peatonal como motorizada. Por último el paisaje urbano está repleto de contenidos, dentro de los cuales se sitúan la propia construcción de la urbe, su color, escala, estilos arquitectónicos, carácter, personalidad, antigüedad, modernidad, unicidad o variedad (Cullen, 1974).

Pues bien, esos caminos que nos llevan hasta la construcción del paisaje y su imagen, pero también soportan el goce estético que de ellos puede derivarse, han de contar necesariamente con la pavimentación. Los pavimentos, junto a las fachadas, tejados, edificios o la vegetación expuesta en la vía pública, son generalmente los primeros elementos paisajísticos que se perciben. El pavimento, su comodidad y funcionalidad como soporte al tránsito, condiciona el itinerario, el tiempo necesario para visitar un lugar, el medio de transporte e incluso la apreciación del resto de los elementos urbanos. Y, en tercer lugar, el pavimento de la vía pública participa de manera destacada en el contenido de la ciudad mediante el color, la textura, las formas o incluso los estilos de sus composiciones y materiales.

Por otro lado, en la construcción paisajística de la ciudad, observada desde los postulados sensitivos e intelectuales de Italo Calvino, esa realidad urbana puede contemplarse como una suerte de enciclopedia o documento que espera ser leído e interpretado (Calvino, 1994; García García et al., 2008). Si la ciudad puede entenderse como un documento dispuesto a ser leído e interpretado en virtud de las vivencias y percepciones humanas, no cabe dejarnos «renglones» sin observar. Nadie experimenta de forma completa y eficaz las bondades o maldades de un libro leyendo sólo las letras capitales de sus capítulos, o sólo leyendo uno de cada diez párrafos. Por ello, el conocimiento (la lectura e interpretación) de la ciudad en general y de la histórica en particular, así como sus atractivos culturales y turísticos no pueden ni deben minusvalorar las funciones, materiales, formas, color, textura y evolución del pavimento de la vía pública, mucho más cuando éste es el sostén del movimiento, la huella del pasado e incluso constituye una parte esencial de las experiencias sensitivas y estéticas de la imagen paisajística urbana. A todo ello se suma la creciente consideración de los pavimentos urbanos como factores relevantes en la propia calidad ambiental de las urbes, a la par que están adquiriendo gran importancia gracias a la instalación de otros nuevos que refuerzan el valor estético y museístico de la vía pública como 
recipientes legibles, pues facilitan la comprensión e integración del pasado y el presente en ciertas ciudades históricas (Figura 1).

Figura 1

DIAGRAMA DE LAS RELACIONES DE INFLUENCIA EN LA CONFORMACIÓN DEL PAISAJE URBANO SEGÚN LA ESTRUCTURA DE LA CIUDAD, EL ESQUEMA DE VALORES Y NECESIDADES, Y EL MERCADO DEL PAISAJE, ASÍ COMO LA INCIDENCIA DEL PAVIMENTO EN EL FENOSISTEMA Y CRIPTOSISTEMA DEL PAISAJE URBANO.

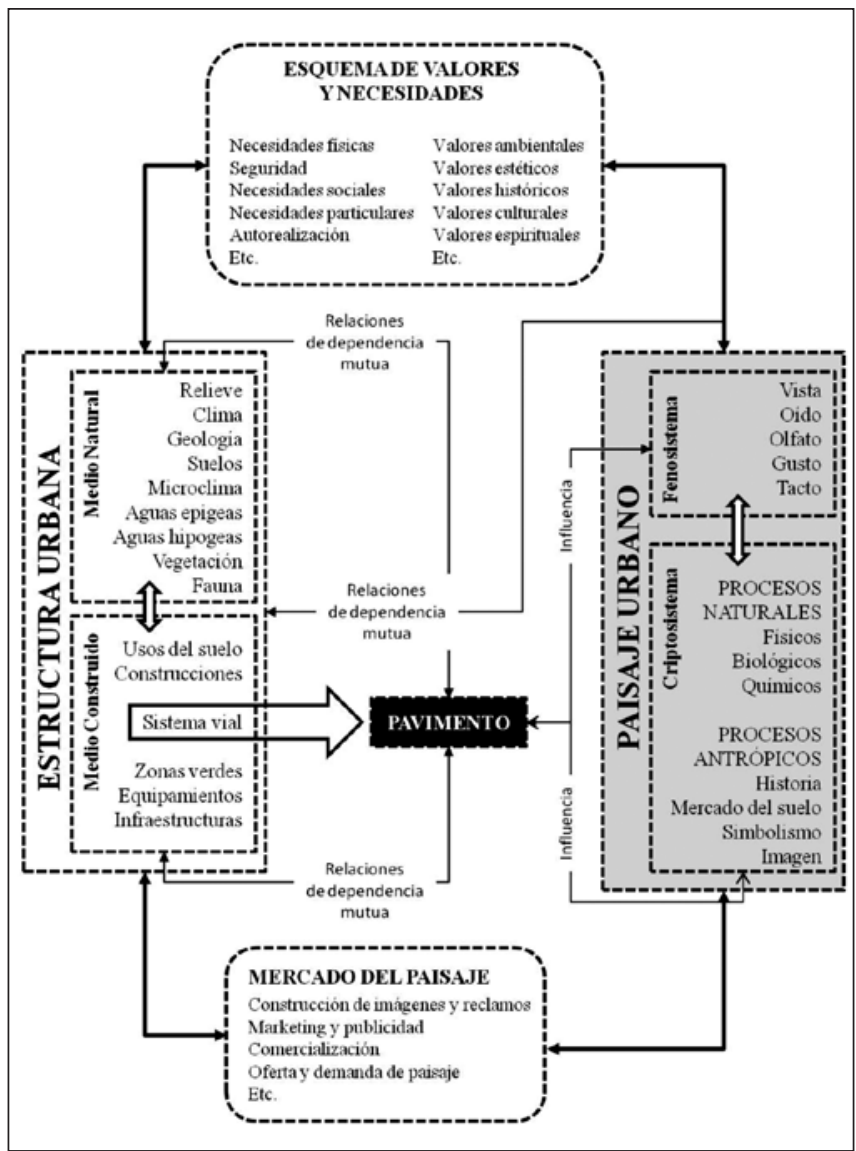

Fuente: Elaboración propia.

Del mismo modo que el suelo de un paisaje rural o natural condiciona y participa en la formación de éste, los pavimentos de las ciudades son una parte esencial de la construcción, constitución y evolución de su identidad, de su patrimonio y de las experiencias de quienes las habitan y visitan. La definición que hagamos del plano del suelo incide en una lectura más clara de la ciudad. Los diferentes materiales, texturas, colores y modos de construcción llevan asociados connotaciones subjetivas (alusiones a contextos urbanos históricos, culturales, o simplemente vivenciales) que nos pertenecen y que contribuyen a la identificación de diferentes ciudades o de zonas de éstas, como el centro o los barrios periféricos (Peinado Margalef, 2011). 
Sin embargo, el aparente carácter inerte de los pavimentos urbanos, así como su artificialidad y su perspectiva casi estrictamente funcional, han sido quizás las circunstancias que han restado relevancia a su análisis en el modelado de las ciudades y sus paisajes. Empero, en los últimos veinte años estamos asistiendo a una destacable revitalización de los pavimentos urbanos, un hecho que, al fin y a la postre, no hace sino reconocer y ponderar la importancia de este elemento en la evolución y en el significado de los paisajes urbanos, pues el desarrollo de estos no puede sustentarse sólo en la construcción de edificios más o menos singulares, en el diseño armónico de sus fachadas, en los servicios urbanos o en la planificación de los espacios abiertos.

Con el fin de sintetizar las repercusiones que sobre la totalidad del paisaje urbano poseen los pavimentos de las vías públicas, vamos a glosar con algún detalle los atributos o circunstancias que mejor ilustran esa influencia, considerando ésta según los componentes fenológicos y criptológicos que conforman cualquier paisaje (Figura 1).

\section{EL «PAVIMENTO LEGIBLE»: LA REFORMA DE LA CALLE «JOSÉ CRUZ CONDE» DE CÓR- DOBA}

Aunque el propósito de este apartado será la descripción y análisis de la reforma llevada a cabo en el año 2011 en la calle José Cruz Conde de Córdoba, no podemos dejar de ofrecer una visión del conjunto territorial urbano del casco histórico de la ciudad en materia de pavimentación, pues la reforma aludida no puede observarse de forma aislada, sino en su contexto territorial, histórico, cultural, urbanístico y turístico.

\section{La pavimentación histórica del casco antiguo de Córdoba}

El conjunto histórico de la ciudad de Córdoba, parcialmente declarado Patrimonio de la Humanidad por la UNESCO, conserva aún pavimentos antiguos cuyo valor cultural y paisajístico queda reconocido en el Plan Especial de Protección del Conjunto Histórico de 2001 (PEPCH’01). Este documento de estudio, diagnóstico y normalización establece cierta reglamentación para la conservación y, sobre todo, la ejecución de nuevas pavimentaciones en el casco histórico de la ciudad, cuestiones que afectan a una superficie abierta y pública que ronda los $400.000 \mathrm{~m}^{2}$. Tales normas se basan en el propósito de mantener los modelos tradicionales mediante el uso de elementos materiales como la losa, el empedrado, adoquines y bordillos, todos ellos de material pétreo, especialmente granito y cuarcita, un material resistente que desde tiempo inmemorial procedía de las canteras paleozoicas de la Sierra Morena cordobesa o de las cercanas graveras de «chino» o canto rodado que se acumula en las terrazas del Guadalquivir y sus aledaños.

El PEPCH’01 nos ofrece un sucinto diagnóstico de la variedad de pavimentos que forman parte de los invariables históricos del casco antiguo. Así, a grandes rasgos, los viales y plazas del centro histórico y turístico de la ciudad cuentan con los siguientes pavimentos tradicionales:

a) Sección de pavimento exterior formado por losa de granito (banda de fachada) + empedrado de chino (banda central de ancho irregular) + losa de granito (banda de fachada). Es el caso con aspecto más tradicional y que mejor identifica al paisaje urbano de la ciudad histórica y su imagen turística (Figura 2). Tanto las losas como el empedrado de chino o «enchinado» cuentan originalmente con una argamasa de 
cohesión formada por una mezcla permeable de cal y arena, si bien las reformas de los servicios subterráneos y el creciente uso del cemento han alterado la permeabilidad originaria.

b) Sección de losa de granito (banda de fachada) + adoquinado de granito u otro material resistente a la rodadura (banda central de ancho irregular) + losa de granito (banda de fachada). A veces las losas de granito se ven sustituidas por estrechos y poco funcionales acerados de anchura irregular con bordillos de granito (u otra roca plutónica) y baldosas de hormigón (Figura 3).

c) Sección de empedrado de chino o canto rodado de anchura irregular (banda de fachada) + losa de granito (banda central) + empedrado de canto rodado de anchura irregular (banda de fachada) (Figura 4).

d) Sección de adoquinado de granito de ancho irregular (banda de fachada) + losa de granito (banda central) + adoquinado de granito de ancho irregular (banda de fachada) (Figura 4). Este tipo, al igual que el precedente, se hace patente sobre todo en plazas y plazoletas del casco antiguo, pues la franja de losa de granito se dispone en el centro del espacio público, facilitando el tránsito peatonal entre las bocacalles más importantes que desembocan en el espacio abierto.

e) Pavimento con sección continua de losas de granito, pues la estrechez de la calle ha eliminado la presencia de ejes centrales de materiales distintos.

f) Pavimento continuo de adoquinado de granito.

g) Pavimento continuo de empedrado de cantos rodados o «enchinado».

h) Por último, cabe señalar la presencia de variantes de los ejemplos anteriores con presencia de despieces del pavimento mediante bandas o cintas de adoquines graníticos o la existencia de modelos condicionados por presentar pendientes o «cuestas» topográficas que se resuelven con gradas delimitadas por bordillos de granito y superficies de canto rodado o adoquines más o menos decorados.

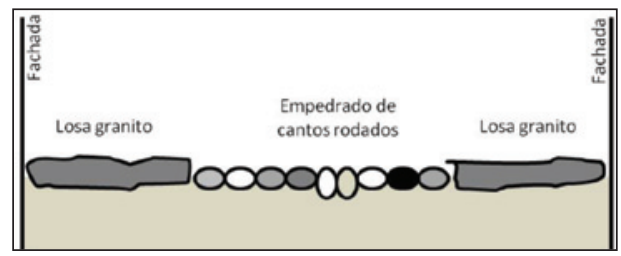

Sección esquemática de pavimento tradicional formada por una banda central de «chino» y sendas bandas junto a las fachadas de la calle cubiertas de losas de granito.

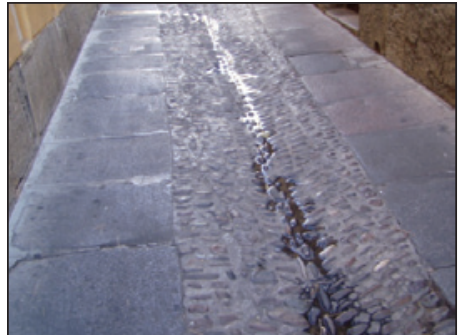

Imagen del pavimento de bandas graníticas laterales y eje central con empedrado de cantos rodados en la calle Almanzor-Romero de Córdoba.

Fuente: Elaboración propia y archivo fotográfico personal. 
Figura 3

SECCIONES E IMAGEN DE PAVIMENTO TRADICIONAL FORMADO POR ADOQUINES DE GRANITO

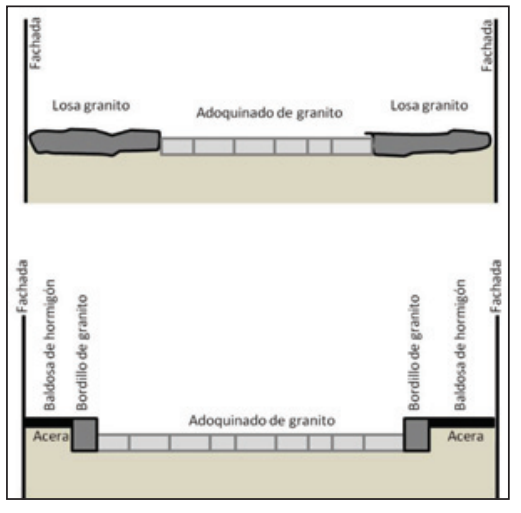

Secciones esquemáticas de pavimentos de adoquines de granito con losa de granito o acerado con bordillo de granito y baldosa de hormigón.

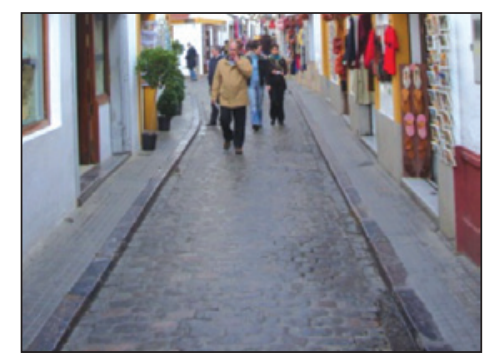

Imagen del pavimento de adoquines centrales y acerados en bandas de fachada en la turística y comercial calle Deanes de Córdoba.

Fuente: Elaboración propia y archivo fotográfico personal.

Figura 4

SECCIONES E IMAGEN DE PAVIMENTO TRADICIONAL FORMADO POR LOSAS DE GRANITO EN SITUACIÓN CENTRAL

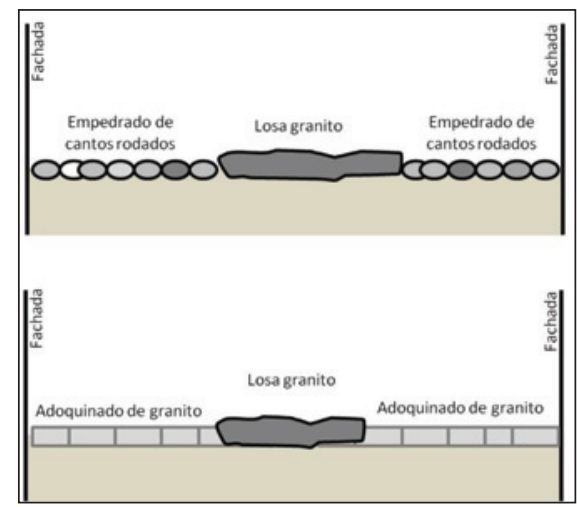

Secciones esquemáticas de los pavimentos con losa de granito en situación central y bandas de fachada de empedrado o adoquines.

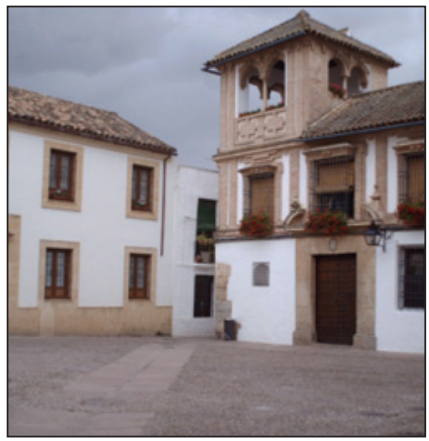

Imagen del pavimento con losas de granito centrales y bandas laterales de empedrado en la plaza de Maimónides de Córdoba, donde se halla el Museo Taurino y el Hotel NH «Amistad».

Fuente: Elaboración propia y archivo fotográfico personal.

Esta breve tipificación, protegida por las normas recogidas en el $\mathrm{PEPCH}^{\prime} 01$, ha sufrido, principalmente en los años cincuenta y sesenta del siglo XX, graves alteraciones. Incluso algunas calles del casco histórico, especialmente indicadas por su anchura y su adaptabilidad al tráfico rodado contemporáneo, fueron asfaltadas, soterrando pavi- 
mentos de «enchinado» o adoquinado. Parecidas circunstancias se dan en otros lugares, vías y plazas del conjunto histórico, pues son muchos los rincones y enclaves públicos que sufrieron la invasión del asfalto y que aún todavía lo conservan, sobre todo porque mantienen el papel que se les otorgó como arterias principales en el flujo de vehículos, si bien muchas también han comenzado a renovar sus pavimentos siguiendo nuevos criterios que intentan conjugar aspectos tan complejos de armonizar como la conservación del patrimonio, la calidad ambiental, la peatonalización, el acceso para discapacitados, el tráfico rodado y las necesidades de aparcamiento, el tráfico de servicios públicos, el suministro de los servicios colectivos o la necesaria revitalización del antiguo casco histórico, donde durante décadas se ha venido registrando una creciente pérdida de población residente (Mulero Mendigorri, 1991).

\section{Las reformas a partir de los años noventa del siglo XX}

$\mathrm{Al}$ amparo de los nuevos principios que sobre la función de la vía pública urbana propugnó el Comité de la Ciudad del Congreso Mundial de Carreteras de Marrakech de 1991, la ciudad de Córdoba, al igual que otras de similar cuño y evolución, comenzó a interesarse por la recuperación y adaptación de los pavimentos históricos. A la revisión de la vía pública como lugar de sociabilidad también se sumó la revitalización de la ciudad histórica como complejo cultural y destino turístico, aspectos que se verían potenciados por la atracción que supuso la EXPO'92 de Sevilla, la declaración de Patrimonio de la Humanidad de la Mezquita de Córdoba en 1984 o la posterior expansión de esa declaración, en 1994, a una extensa zona urbana de su Centro Histórico. No podemos olvidar que a lo anterior se suma la creciente importancia de la visión ambiental en la ciudad o la no menos responsabilidad e imperativo legal que supone la accesibilidad universal (Salas Mozos y Alonso López, 2005; Herce Vallejo, 2009; Corral, 1992 y 1998).

En consonancia con tales propósitos, también hemos de mencionar el avance del propio sector de los pavimentos, especialmente urbanos, pues ha conocido en ese mismo período de tiempo una increíble expansión y un inusitado desarrollo en materia de innovación tecnológica y materiales, lo que ha provocado un incremento muy razonable de la oferta, así como la incorporación de pavimentos urbanos que hace un par de décadas nos podían parecer, cuando menos, inviables.

Tales hechos se comienzan a recoger, en el caso cordobés, en el PGOU de 2001, en el PEPCH del mismo año y, de forma más específica en materia de accesibilidad, en el Plan de Accesibilidad del casco Histórico de 2006 o el Plan de Movilidad Urbana Sostenible. La labor del planeamiento y de las directivas en materia de pavimentación urbana histórica se verán condicionadas por ese nuevo escenario marcado por los principios de las nuevas necesidades que la sociedad demanda de las vías públicas, unas necesidades que, todo sea dicho, han aumentado sus exigencias respecto a los atributos que se reclaman y que persiguen la conjunción de la estética, la conservación, calidad ambiental, transitabilidad, confortabilidad, impulso y calidad turística, desarrollo económico y revitalización demográfica, accesibilidad universal, etc. Tales son esas exigencias, todas legítimas, que no resulta extraño que surjan corrientes contradictorias, posturas encontradas y tensiones respecto a las reformas en materia de pavimentación, sobre todo en cascos históricos como 
el de Córdoba, cuya extraordinaria extensión ya supone un problema para su gestión y desarrollo, a lo que cabe sumar su propia heterogeneidad demográfica, social y económica.

Con el propósito de acercar la realidad patrimonial urbana de Córdoba a los principios y medidas referidas, a sabiendas que se trata de un propósito de extraordinaria dificultad, el municipio cordobés ha acometido una importante modernización y adaptación de los pavimentos de la ciudad histórica. Tales reformas han afectado a plazas y vías de la «Villa» y la «Axarquía» de la ciudad ${ }^{4}$, destacando en especial ciertos ejes y enclaves de gran repercusión en la identidad y funcionalidad turística del casco antiguo y de su área declarada Patrimonio de la Humanidad. Podemos destacar la reforma y adecuación del bulevar del Gran Capitán, el eje Concepción-Gondomar, la calle Lucano, la plaza de Jerónimo Páez, la zona verde y el acceso a la Puerta de Almodóvar, las inmediaciones de la Mezquita y Puerta de «El Puente» o la intensa transformación llevada a cabo en la plaza de «La Corredera» (Naranjo Ramírez y López Ontiveros, 2011a y 2011b). A ellas se suma el eje formado por la calle José Cruz Conde, plaza de «Las Tendillas», calle Jesús y María y Blanco Belmonte (Figura 5). Así mismo han de sumarse nuevas actuaciones previstas para los próximos años y que afectarán a otros rincones y calles principales de la urbe histórica, unas reformas que seguro habrán de cambiar la imagen, la economía y la función de uno de los cascos históricos más extensos de Europa.

Ahora bien, todo hay que decirlo, no cabe duda que tales reformas y mejoras están provocando una revitalización del casco histórico cordobés, sacándolo de un duradero entumecimiento o incluso de la destrucción patrimonial ${ }^{5}$. Lo que no es tan evidente son las consecuencias que tal revitalización trae y traerá consigo, pues toda alteración representa cambios de signos dispares que habrán de examinarse y valorarse mediante criterios de sostenibilidad ambiental, patrimonial, social y económica. En caso contrario, quizás estemos asistiendo, en Córdoba y otros centros históricos similares, a una revitalización abocada al suicidio patrimonial de la ciudad antigua, a la construcción de una realidad y una imagen exclusivamente turística y banal, a la especulación del suelo y sus aprovechamientos, a la terciarización desmedida del espacio urbano y a la mutación de una imagen paisajística y patrimonial que durante siglos ha sido el recipiente virtual y tangible de la identidad cultural y social de la población autóctona.

4 Es conocido que la Córdoba medieval tardoandalusí y cristiana constituía una estructura urbana compleja, pues integraba dos áreas urbanas segregadas físicamente e individualizadas por sendas murallas. La antigua «Medina», emplazada sobre los vestigios de la vieja ciudad romana, forma, tras la cristianización de la ciudad, la denominada «Villa». A levante de ésta y con una muralla propia, se extiende la «Axarquía». Ambas unidades urbanas han pervivido hasta nuestros días con notables reformas y adecuaciones, aunque conservando la identidad de espacios urbanos históricos (López Ontiveros, 1981 y Escobar Camacho, 1989).

5 Esa postración-desaparición cultural, simbólica y material del casco histórico cordobés la enunciaba en 1973 el psiquiatra Carlos Castilla del Pino, en un artículo titulado «Apresúrese a ver Córdoba» y publicado en el $\mathrm{n}^{\circ}$ 538 de la revista Triunfo (de 20 de enero de 1973); y posteriormente incluido en su obra autobiográfica titulada $L a$ Casa Del Olivo. Autobiografía (1942-2003), editada en 2004. 


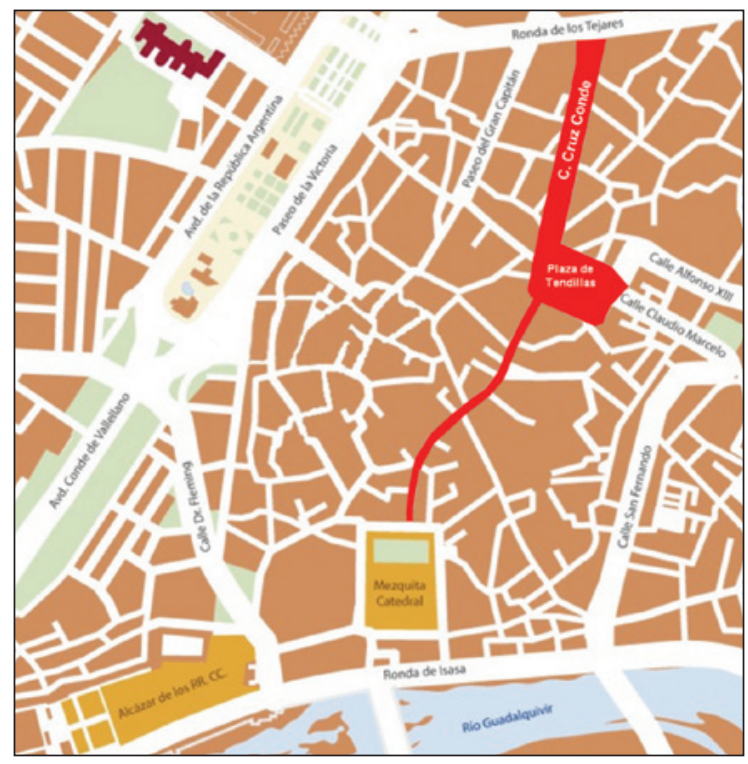

Fuente: Elaboración propia.

\section{Las reformas en la calle «José Cruz Conde»}

La calle José Cruz Conde, o sencillamente «Cruz Conde», constituye un ejemplo ideal de la modernización de la trama histórica de la ciudad de Córdoba, al igual que lo son otras vías como el Paseo del Gran Capitán, las calles Concepción y Gondomar, la calle Claudio Marcelo o la propia plaza de «Las Tendillas». Todos estos espacios públicos resultan de la adaptación de una trama viaria heredada que a duras penas, a finales del XIX y primera mitad del siglo XX, podía satisfacer las nuevas necesidades motivadas por la llegada del ferrocarril, el derribo casi total de las antiguas murallas o el desarrollo de los transportes motorizados. Así mismo, no podemos menospreciar la influencia del componente sociológico y las necesarias operaciones de higienización que la apertura de nuevas calles y ensanches representaban en un plano urbano que prácticamente había permanecido inalterable desde la Edad Media y seguía presentando un entramado arborescente.

En la segunda mitad del XIX y primeras décadas del XX se abordarán esas operaciones de cirugía urbanística que, en último extremo, persiguen el desarrollo de una nueva centralidad que rememora los orígenes fundacionales romanos. Una centralidad que habría de gravitar alrededor de la transformación de la plaza de «Las Tendillas» y sus vías adyacentes. Al fin y a la postre, no sólo se modificaba la realidad física del casco histórico cordobés, pues paralelamente se reorganizaba el mapa económico, simbólico y social de la ciudad, dando paso a una centra- 
lidad burguesa que hacía las veces de escaparate urbano para las familias acomodadas y donde éstas podían satisfacer sus demandas comerciales y de ocio (García Verdugo, 1992). Un nuevo centro que aún conserva parte de esos atributos y su relevancia económica en el contexto de la ciudad, a expensas de haber alterado de forma imborrable el paisaje de la ciudad heredada. En la actualidad ese nuevo centro, gestado entre el XIX y el XX, se enclava en el área noroccidental de la antigua «Villa» cordobesa y se le conoce como el «Centro Comercial», ocupando una extensión de 45'5 Has articuladas mediante el Paseo del Gran Capitán, las calles Concepción y Gondomar, la calle José Cruz Conde, la plaza de «Las Tendillas» y la calle Claudio Marcelo (Martín López, 1986 y 1990; García Verdugo, 1986).

La apertura de la calle José Cruz Conde, una de las últimas operaciones de esta índole, se realiza sobre el entramado urbano primitivo de la «Villa» cordobesa, una red de calles estrechas y «azucaques» («cul-de-sac») que definían compactas, extensas y continuas manzanas y un viario estrecho y discontinuo. Sobre dicha trama se programa y ejecuta la apertura de una nueva vía, amplia y rectilínea, creada para comunicar con fluidez el ensanche de la plaza de «Las Tendillas» con la ronda norte de Tejares, levantando en sus márgenes nuevos y nobles edificios para viviendas de familias acomodadas, locales comerciales e incluso establecimientos gubernamentales como la sede de Correos y Telégrafos, que fue erigida en 1945.

Representaba una importante reforma que incluía el adecentamiento urbano y arquitectónico del sector afectado, la mejora del pavimento, pues se introdujo el adoquinado de granito, así como la construcción de amplios acerados que facilitaran el paseo de esa clase acomodada. Al mismo tiempo, su ejecución arrojó unos resultados culturales y paleourbanos muy significativos, pues la operación proporcionó nuevos datos arqueológicos sobre el pasado medieval y romano de la ciudad (Santos Jener, 1944 y 1945).

En los años sesenta del siglo XX, una vez consolidado el carácter económico del «Centro Comercial» alrededor de aquellas actuaciones urbanísticas, la calle José Cruz Conde conocerá una nueva reforma con el fin de mejorar su aspecto peatonal y, sobre todo, con el fin de fortalecer aún más su papel como eje de circulación rodada. En dicha reforma se procedió al asfaltado de la calzada y se ensancharon y embaldosaron los acerados, adquiriendo el aspecto que, con reformas puntuales, ha mantenido hasta finales del año 2010 (Figura 6).

Figura 6

IMAGEN RECIENTE DE LA CALLE JOSÉ CRUZ CONDE EN 2010, ANTES DE LA PEATONALIZACIÓN Y REFORMA DE SU PAVIMENTO

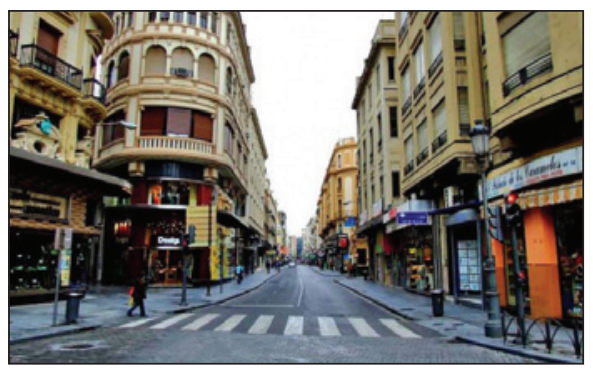

Fuente: Fototeca del Archivo Municipal de Córdoba
Figura 7

IMAGEN ACTUAL, TRAS LA REFORMA LLEVADAA CABO EN 2011, DE LA CALLE JOSÉ CRUZ CONDE. LA INSTANTÁNEA ESTÁ TOMADA EL 4 DE SEPTIEMBRE DE 2012

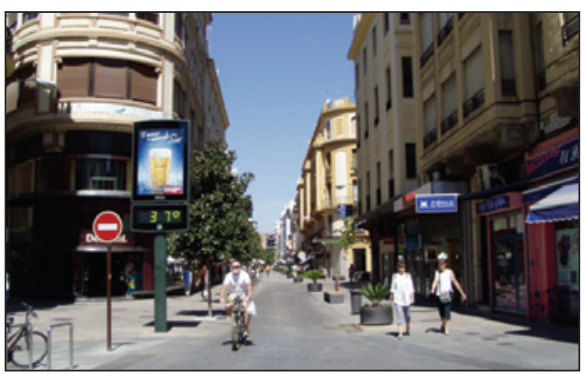

Fuente: Archivo fotográfico propio. 
A principios del siglo XXI la calle José Cruz Conde iniciará su más reciente y drástica metamorfosis. Un giro que la haría pasar de ser una importante y original arteria de comunicación rodada en pleno casco histórico de Córdoba, a convertirse en una moderna calle peatonal o semipeatonal, en cuyo pavimento se han introducido innovaciones en materia patrimonial, cultural y urbana, acompañadas de una no menos importante adecuación a la accesibilidad universal (Figura 7). Una accesibilidad que une la periferia norte con el centro turístico cordobés y su antigua Mezquita. La calle Cruz Conde nació con el propósito de mejorar las condiciones del tráfico rodado en esa nueva centralidad comercial y social que giraba alrededor de la plaza de «Las Tendillas». Más de medio siglo después, la misma calle se reinventa y adapta a las nuevas exigencias de la ciudad, dando ahora respuestas a las necesidades de peatonalización, accesibilidad y humanización del paisaje urbano del todavía importante eje comercial y de creciente interés turístico. No en vano se transforma en la puerta de acceso cultural del ya referido eje, a lo que se suma la existencia de una amplia oferta comercial, alojativa, financiera, turística y restauradora que ha de resultar de particular interés al visitante.

El proyecto comenzó a esbozarse en el año 2008, pero su ejecución tuvo que aguardar a finales de 2010 y mediados de 2011. En el verano de 2012 la reforma está prácticamente concluida y los resultados han levantado polémica y opiniones encontradas en la ciudadanía cordobesa. Controversias que, por otra parte, han de existir y son necesarias, pues gracias a ellas se construye la imagen y el significado de los lugares que componen una ciudad y que proporcionan significado y sentido social y cultural a su collage paisajístico. A la vista de lo ejecutado han aparecido, como decimos, distintas posturas encontradas. Unos ponen en tela de juicio la idoneidad de cubrir la totalidad del pavimento de la calle con losas de granito; mientras otros valoran positivamente esta solución. Ciertos colectivos abogan por la peatonalización total del vial, mientras otros apuestan por una solución más flexible al tráfico rodado, pues la desviación total del tráfico incide negativamente en la población residente, ciertos negocios o incluso provoca alteraciones en los viales elegidos como alternativos. Y tampoco faltan tensiones entre diferentes sectores económicos y sociales, pues cada cual desea que el nuevo escenario resulte lo más ventajoso posible a sus intereses particulares, tan lícitos como, en ocasiones, insolidarios y egoístas ${ }^{6}$. A continuación ofrecemos algunas de las circunstancias que definen esta importante y original reforma. Importante por su dimensión urbana y sus repercusiones económicas, sociales, paisajísticas y turísticas. Y original por ser el primer ejemplo a gran escala en la ciudad que introduce herramientas de accesibilidad tiflológica para la población invidente, a lo que se suma un diseño cultural y patrimonial que permite leer el pasado urbano y arqueológico de la ciudad en el pavimento actual.

\subsection{Materiales y diseño}

El material predominante, como lo ha sido también en otras vías del casco histórico recientemente reformadas, es el granito natural, un material que, como ya hemos mencionado en nuestra exposición, se halla estrechamente unido a la imagen histórica de la vía

6 Las diatribas provocadas por la reforma llevada a cabo en la calle José Cruz Conde cuenta con una nutrida colección de opiniones y críticas. Éstas se han ido plasmando en foros y prensa local, particularmente en las ediciones del Diario Córdoba (http://www.diariocordoba.com/), ABC (http://www.abc.es/cordoba/index.asp) o El Día de Córdoba (http://www.eldiadecordoba.es/). 
pública. Pero no se trata de una única tipología granítica, ya que el granito empleado presenta múltiples colores, texturas, acabados y formas. Por tanto, nada más lejos de la homogeneidad, pues colores, texturas y formas se ordenan en la vía para diferenciar áreas, espacios y signos que facultan una utilidad plural de la calle e incluso su lectura histórica. En todo caso, aunque el material empleado es el acorde con la tradición urbanística cordobesa, no podemos decir lo mismo con la morfología y acabado utilizados, igual que la procedencia. Los acabados y formas del granito utilizado en nuestras calles históricas presentan un aspecto tosco y rudo, y en muy pocas ocasiones son piezas tipo baldosa. Así mismo, también cabe mencionar que, mientras el granito del casco histórico de Córdoba es una piedra natural local o cercana a la ciudad, los granitos utilizados en el nuevo pavimento son eminentemente importados.

Para la zona pavimentada de tonalidad más clara se han instalado baldosas de tres tipos distintos de granito rosa («portugués», «monforte» y «alba»). Mientras en la zona más oscura se usa granito gris, en sus variedades «negro», «quintana» $\mathrm{y}$ «blanco». Por otro lado, la morfología de las piezas de piedra natural utilizadas también ofrece una significativa heterogeneidad. Mientras en las áreas reservadas al tránsito peatonal se han elegido baldosas de dimensiones dispares, modalidad con poca tradición en los pavimentos históricos de la ciudad antigua; en el área con previsión de uso para el tráfico restringido se ha utilizado adoquín de dimensión y coloración homogéneas.

Al uso de la piedra natural se suma el empleo de latón dorado, elemento que, insertado en la piedra para marcar áreas y zonas precisas, es un aspecto muy destacable en el acabado estético y en la lectura arqueológica y paleourbana del nuevo pavimento. DE LA CALLE JOSÉ CRUZ CONDE; Y LA TRAMAACTUAL

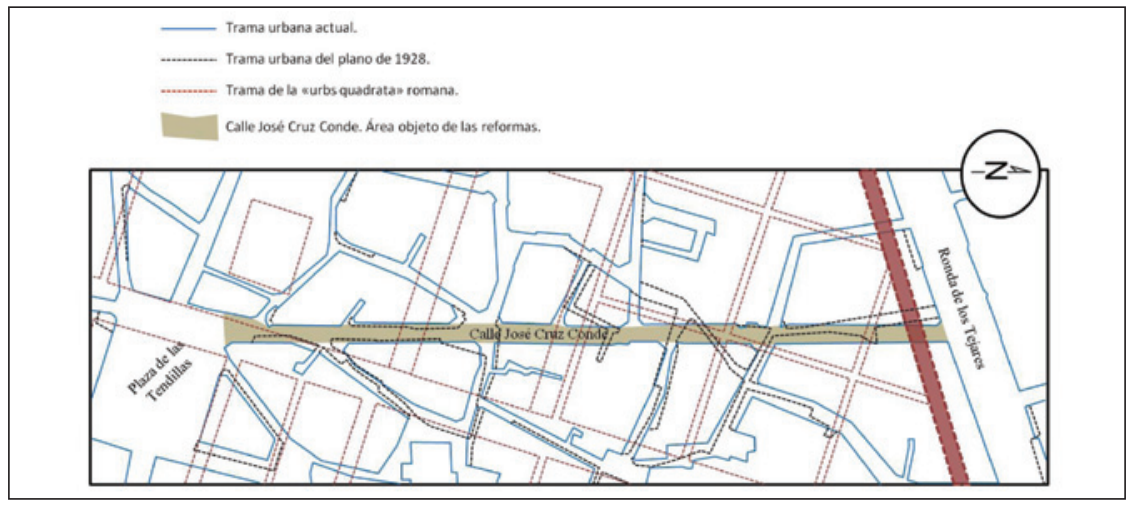

Fuente: Elaboración propia sobre esquema de la Gerencia Municipal de Urbanismo de Córdoba.

El complejo diseño empleado unifica, por un lado, las funciones previstas para la calle como vías para el tránsito y, al mismo tiempo, el uso de una serie de marcas, colores, líneas y texturas que trasladan al pavimento la arqueología del subsuelo, plasmando en la nueva cubierta la localización del antiguo foro romano colonial y el trazado urbano de calles y man- 
zanas existente antes de la apertura, a mediados del siglo XX, de la calle José Cruz Conde. Este diseño nos resulta de extraordinario interés, pues, a la postre, representa una clara evidencia de la convivencia entre el pasado y el presente de una ciudad en permanente mutación. Al mismo tiempo, otorga al pavimento la facultad de convertirse en un verdadero documento cultural legible, que refuerza su valor patrimonial y turístico, acentuando la imagen del urbanismo como una sucesión de momentos y realidades efímeras que mutan y se renuevan.

La funcionalidad vial de la calle segrega, mediante el uso de losas y adoquines, con la ayuda de otros elementos complementarios como la localización del mobiliario urbano, alcorques y maceteros, el área peatonal del medio previsto para el uso restringido de vehículos, aspecto éste que aún está por definir dada la fragilidad del asunto y el valor estratégico que se le sigue atribuyendo a la movilidad rodada como motor de crecimiento. El proyecto inicial, empero, establecía la posibilidad de un uso regulado semipeatonal. Se diseña como estrictamente peatonal el trayecto desde Ronda de Tejares hasta la intersección con la calle Conde de Robledo. A partir de esta vía, en dirección a la plaza de «Las Tendillas», la calle se divide tripartitamente. Al centro se dispone una calzada con posibilidad de soportar un tráfico restringido para residentes y servicios públicos; y en las márgenes unos amplios acerados de baldosas de granito.

Figura 9

IMÁGENES QUE ILUSTRAN EL DISEÑO PATRIMONIAL Y CULTURAL DE LA REFORMA PAVIMENTAL DE LA CALLE JOSÉ CRUZ CONDE

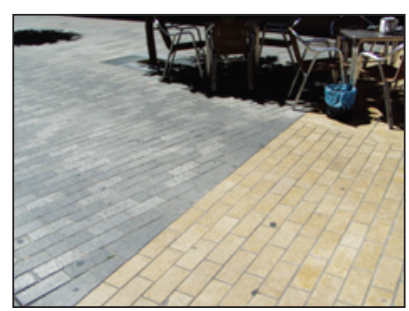

Con materiales diferentes se señala la huella de la antigua muralla romana, junto a la actual Ronda de Los Tejares.

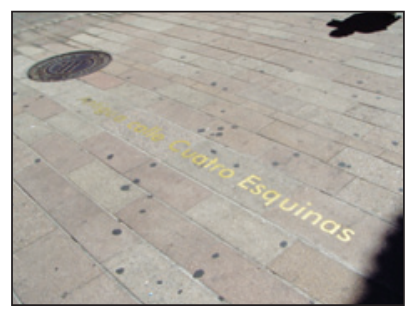

Señalización de antigua calle de la ciudad antes de la apertura de la calle José Cruz Conde. Las antiguas vías se definen en el pavimento de losas de granito rosa y su identificación en letras realizadas en latón. Desaparecida calle de las Cuatro Esquinas.

Fuente: Archivo fotográfico personal.

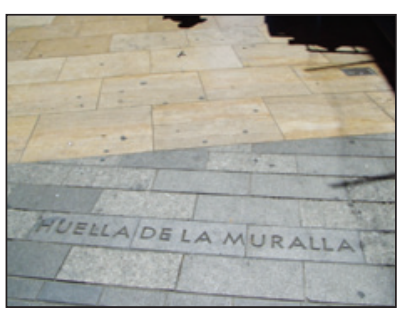

La huella de la muralla queda plasmada también en forma epigrafiada en el pavimento.

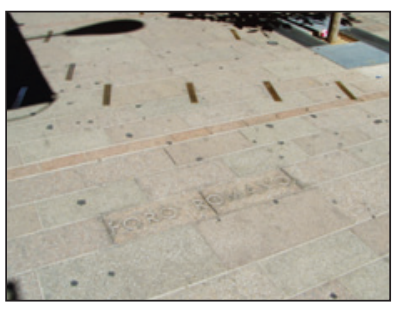

Con láminas de latón dorado se señala la huella del antiguo emplazamiento del foro colonial romano, a lo que se suma el epigrafiado en el pavimento. 
Pero más original e interesante culturalmente es el diseño que, sobre la división anterior, nos ofrece la reforma (Figura 8). Lo ejecutado convierte al pavimento en un plano, un mapa histórico de la evolución de la ciudad a escala 1:1. Utilizando el diferente color del granito y el adecuado uso de las inserciones de latón, el pavimento muestra e ilustra con textos grabados en el pavimento o nuevas inserciones de latón, la localización de la antigua muralla que delimitaba la ciudad junto a Ronda de Tejares; la localización del antiguo foro colonial romano; o la distribución de calles y áreas edificadas existentes a principios del siglo XX según el plano de Uriol de 1928.

Como hemos citado, la calle ya no sólo es un camino más, se convierte en un plano exacto y a escala real que hace patente el pasado en el presente, otorgando al pavimento, al «suelo», el aspecto de un palimpsesto en el que afloran las calles extintas o los elementos más característicos de la ciudad romana, acompañados de los textos que las identifican. Todo ello facilita la imaginación del pasado en el presente y, por añadidura, impulsa a reflexionar sobre el concepto de ciudad, de espacio y de tiempo, cuestiones todas ellas de carácter transcendental para la construcción del futuro (Figura 9).

\subsection{Peatonalización y accesibilidad}

Ya hemos citado que la accesibilidad en el diseño de la ciudad y sus vías públicas, así como en la obra arquitectónica, no sólo es hoy una cuestión ética. Es igualmente un imperativo legal que, sin embargo, no resulta fácil cumplir cuando se trata de hitos o espacios patrimoniales históricos. Estos no fueron construidos utilizando principios de accesibilidad contemporáneos y su protección, también por imperativo legal, no facilita siempre la accesibilidad universal. ¿Cómo hacer hoy accesible un lugar o monumento que se construyó en su tiempo para no serlo? ¿Cómo alterar el aspecto o la estructura de un monumento protegido para hacerlo accesible? No cabe duda de que no es fácil, pero también es cierto que en muchas ocasiones se han conseguido fórmulas simbióticas entre los propósitos de la conservación y la accesibilidad.

La ciudad de Córdoba, consciente del interés por eliminar barreras y de que la accesibilidad urbana ha de ser un valor añadido en el posicionamiento turístico de su casco urbano, ha desarrollado numerosas acciones para mejorar el acceso a servicios públicos, monumentos singulares y museos, etc. Al mismo tiempo, de la mano de las ordenanzas municipales $(1994)^{7}$, del referido Plan de Accesibilidad al Casco Histórico o del Plan Municipal de Actuación Integral con Personas con Discapacidad (2005-2010), ha evaluado el grado de accesibilidad de las vías del conjunto y, en las reformas acometidas ha introducido un buen número de mejoras para facilitar el acceso a lugares y permitir el tránsito en el interior de ellos.

La reforma de la calle José Cruz Conde no ha permanecido al margen de los principios, normas y recomendaciones al respecto de la accesibilidad universal. El primer aspecto de la accesibilidad de la reforma ha sido el principio de peatonalización o semipeatonalización que ha conservado el proyecto. Esta fórmula, que aún está por definirse en su estado final, ha hecho de la calle un medio que rápidamente ha sido colonizado por los peatones, los que

7 Ordenanza municipal sobre supresión de barreras arquitectónicas, urbanísticas, en el transporte y en la comunicación sensorial (B.O.P. nº 162, de 15 de julio de 1994). Modificaciones en el B.O.P. nº 181 , de 6 de agosto de 1994. 
pasean o los que utilizan la bicicleta. A este diseño mayoritariamente peatonal o, en todo caso, de tráfico restringido, se suma la reforma y mejora, mediante rampas, de los accesos a la calle desde sus vías adyacentes; así como un adecuado diseño y equipamiento podotáctil del nuevo pavimento instalado.

El uso de baldosas y adoquines de piedra granítica con acabado antideslizante, la conservación de una única rasante o el empleo de alarmas y defensas podotáctiles en el pavimento son algunas de la mejoras introducidas. Algunas de ellas pioneras en el contexto de la vía pública cordobesa. En materia de pavimento podotáctil, aquél que mediante una lectura táctil permite y facilita la accesibilidad y el encaminamiento a invidentes y personas con discapacidad, cumple su función gracias a su contraste táctil y visual. Por ello los pavimentos que presentan de forma ordenada tales elementos son fácilmente identificables e incluso evitan el deslizamiento en condiciones de humedad, lluvia o hielo. La reforma ha introducido baldosas y otros elementos pétreos con acabados podotáctiles, especialmente el de tipo acanalado, especialmente indicado para marcar la proximidad del área central de potencial tráfico rodado.

Pero no queda en esto el uso de herramientas que facilitan la accesibilidad. También se han reducido y cubierto mediante rejillas metálicas los alcorques para las plantas ornamentales; e incluso se han instalado en el pavimento luces «led» ornamentales y guías para la referencia de los espacios, una instalación que ha generado un especial interés estético entre los ciudadanos. Tales mejoras, a nuestro modo de ver, convierten a la calle reformada en el mejor exponente de la accesibilidad en la ciudad de Córdoba, superando a las llevadas a cabo en otros ámbitos cercanos. Si bien tales mejoras no podrán evaluarse en su justa medida hasta disponer de una adecuada perspectiva de su uso y hasta conocer la valoración de la población con mayores exigencias en esta materia.

\subsection{Las consecuencias de las reformas}

Preguntarse por las consecuencias de la remodelación llevada a cabo es un ejercicio predictivo aventurado, ya que sus resultados sólo podrán conocerse con detalle a medida que dispongamos de una perspectiva temporal del nuevo escenario. Sin embargo, consideramos necesario esbozar al menos algunas circunstancias que nos parecen, por el momento, evidentes.

La reforma llevada a cabo, dada su dimensión espacial y la relevancia de su situación en el conjunto de la ciudad, acarrea consecuencias que afectan tanto al área estrictamente modificada, como a la totalidad del escenario y el sistema urbano de la ciudad. Con ello, siguiendo los postulados teóricos de la teoría de sistemas, es factible afirmar que la reforma de la calle José Cruz Conde supone no sólo una mejora puntual del pavimento, sino que se convierte en un claro exponente de revitalización y adaptación del conjunto de la urbe. Todo ello, por supuesto, avala la importancia que en la actualidad poseen los pavimentos de las calles y plazas como elemento estructural de la ciudad contemporánea, así como los efectos que estos tienen en la evolución y construcción del territorio, las funciones de la ciudad y su paisaje.

Las consecuencias perceptuales de la remodelación se hacen especialmente evidentes en los lugares y rincones de la propia vía o en sus espacios adyacentes. La remoción material, estética y ornamental ha cambiado de forma sustancial la armonía de colores, texturas y elementos que configuraban la estampa de la calle, afectando igualmente a percepciones más allá de lo estrictamente visual. La nueva piel del pavimento, la introducción de plantas orna- 
mentales, maceteros, bancos, fuentes o la restricción del tráfico rodado han proporcionado un drástico giro en las percepciones de la vía, acrecentando con ello los valores estéticos y sensitivos de la misma y también de las construcciones que la flanquean. En este sentido cabe mencionar que se han reducido de manera destacada los niveles de estrés y alteración ambiental, sobre todo gracias a la exclusión del tráfico rodado.

Los efectos simbólicos sobre el paisaje también son evidentes, aunque éstos se construyen con el tiempo. La reforma refuerza el significado y la imagen central que ya poseía la calle desde mediados del siglo XX en el contexto de la ciudad histórica y contemporánea. Sin embargo, esa imagen, asociada desde tiempo atrás a los usos comerciales y residenciales de las familias acomodadas de Córdoba, se matiza con nuevas ideas y funciones. En principio, la nueva calle y su pavimento están adquiriendo una imagen de modernidad y accesibilidad que no poseían, a lo que se suman unos indudables valores culturales y de ocio relacionados con el paseo y el desarrollo de un espacio público peatonal a modo de salón urbano y público. Esta imagen, ciertamente, no es nueva para la calle Cruz Conde, pues en los años sesenta del siglo XX era un medio especialmente valorado como lugar de relación social.

Pero las consecuencias también se adivinan más allá de la escala espacial cercana a la propia calle, adquiriendo proporciones territoriales de ciudad. La atracción económica de la vía respecto a otros espacios urbanos, la necesaria redirección del tráfico rodado por vías alternativas y otras circunstancias similares han de alterar los flujos, funciones y realidades paisajísticas del conjunto del casco histórico de la ciudad y su periferia, así como también habrá de alterar los movimientos de la población local y visitante.

Los efectos económicos resultan complejos y variopintos. Los de tipo urbanístico no se han hecho esperar, pues la reforma ha supuesto una revitalización del precio del suelo, edificios y alquileres situados en las fachadas de la vía o en las calles próximas y afluentes ${ }^{8}$. Tan significativas consecuencias económicas están comenzando a alterar el mapa comercial y socio-económico de la vía, pues quizás el resultado más evidente está siendo la creciente invasión de terrazas de bares, tabernas y restaurantes que adivinan con prontitud los atractivos que se derivan de la peatonalización de una calle céntrica, con residentes de clase acomodada, repleta de comercios y situada a las puertas de un importante eje cultural y turístico que conecta con el principal monumento de la urbe. En este sentido uno de los riesgos más evidentes de la nueva situación es el «secuestro» de la vía pública por parte de veladores y terrazas, efecto que ya resulta evidente en otras calles del casco histórico de la ciudad y que multiplica generalmente el número de barreras en la vía, así como una indudable privatización funcional del espacio público.

Las consecuencias culturales también las creemos muy relevantes. El principal aspecto que avala este resultado se deriva del propio diseño paleourbano que se ha otorgado al pavimento mediante el uso de códigos cromáticos y epigrafía pavimental. Este tratamiento fortalece las potencialidades del suelo de la vía como soporte legible e interpretable en clave patrimonial, capaz de servir de pretexto para reforzar la idea de ciudad como acumulado arqueológico, histórico y urbano, así como para servir de ejemplo ilustrativo de actividades culturales, educativas y turísticas. En esta línea cabe señalar que la epidermis cultural del nuevo pavimento nos invita a mirar al suelo para descubrir la narración de su acabado, una narración que nos impulsa a

8 Al respecto podemos citar la noticia publicada en el Diario Córdoba del 2 de octubre de 2011. 
observar el pavimento como una obra de arte en sí misma, plagada de colores, texturas y materiales capaces de trasladarnos a otro tiempo y a «otra ciudad».

En último lugar, la remodelación del pavimento y las funciones viales de la calle, asociadas al conjunto de vías y ejes de comunicación en el casco histórico y en su periferia, habrá de proveer una metamorfosis de los flujos turísticos. Mucho más cuando, como ya hemos mencionado, la situación de la calle en el eje «Las Tendillas»-Jesús y María-Blanco Belmonte le confiere el carácter de puerta norte del acceso al centro turístico de la ciudad. Así mismo, el diseño cultural y los abundantes servicios comerciales y de restauración con los que ya cuenta la calle, fortalecerán la atracción y el flujo turístico, más aún cuando se halla en un punto intermedio entre ese centro turístico y equipamientos como la Estación AVE y la Estación de Autobuses.

\section{CONCLUSIONES}

La compleja realidad cultural, patrimonial y paisajística de cualquier ciudad, tras las reflexiones y ejemplos generales y concretos que hemos expuesto, no puede desmerecer o despreciar los valores y el significado del pavimento de la vía pública como parte muy relevante de la estructura urbana. Es más, aunque la desmedida visión funcional de los pavimentos ha reducido tal perspectiva, el pavimento de calles, plazas y jardines puede ser también un elemento patrimonial y puede atesorar valores intrínsecos que han de ser protegidos. Ello, por supuesto, no ha de observarse como una salvaguarda a ultranza de la realidad física del pavimento de las ciudades o de sus cascos históricos. Las particularidades físicas y funciones a las que están destinados los pavimentos públicos propician su deterioro y necesaria remodelación. Pero esas obligadas reformas y sus proyectos, además de cumplir con las normas y las especificaciones técnicas que le son propias, deben también examinar su valor patrimonial, especialmente si se trata de áreas históricas, las consecuencias paisajísticas y perceptivas que sus reformas representan, y el significado que poseen en la construcción y evolución de la imagen cultural, histórica y turística. Así mismo, lejos de criterios estrictamente técnicos o constructivos, el pavimento no ha de considerarse un elemento pasivo en la narración y la interpretación de la ciudad, ya que influye en el fenosistema y el criptosistema del paisaje urbano, en la calidad ambiental, la movilidad y el confort de la población, la higiene de la ciudad, su dinamismo económico, sus relaciones interpersonales, etc. Incluso, con la renovación que se está viviendo en este campo, el pavimento puede convertirse en un apropiado «lienzo» en el que reflejar el pasado cultural, urbano y patrimonial, con incidencia en la economía, la sociedad y la industria turística de un determinado destino.

Para ilustrar ese protagonismo de los pavimentos en la construcción del paisaje urbano, especialmente en los de carácter histórico, hemos examinado la reforma del pavimento de la calle José Cruz Conde de Córdoba. En ella, y más aún tras su reforma, se concilian el pasado y el presente de la visión cultural de la ciudad como recipiente de los cambios sociales, catalizando una importante reinvención del centro comercial de la ciudad histórica, y constituyendo una significativa bisagra urbana entre la periferia y el centro turístico por excelencia de la urbe. Su apertura «ex novo» en la primera mitad del siglo XX vino a potenciar la creación de una centralidad económica y social en la trama urbana heredada de siglos pasados. Casi cien años después, gracias a la reforma que hemos descrito en estas páginas, la calle (y su pavimento), se ha reinventado y fortalecido como centro de la ciudad. Pero esa reinvención 
no se ha sustentado sólo en la modernización, la accesibilidad universal o el acceso a las nuevas tecnologías; también ha sabido mirar al pasado, a la cultura, a la arqueología y a «las ciudades» sobre las que se cimenta la aglomeración actual, tanto sus barrios antiguos como las expansiones más recientes y periféricas.

Sólo el paso del tiempo, la perspectiva histórica, y el análisis de los usos y abusos que puedan producirse tras la reforma, nos darán la distancia suficiente como para valorar con propiedad los aciertos o desaciertos del proyecto ejecutado. Pero lo que no cabe duda es que la remodelación del pavimento ha originado una drástica metamorfosis de la calle como espacio vivencial, funcional y estético; un cambio que, por supuesto, se deja sentir en el conjunto de la ciudad, en su imagen, paisaje y paisanaje.

\section{BIBLIOGRAFÍA}

AJRAM, K. (1992). The Miracle of Islam Science. 2nd Edit. Knowledge House Publishers. ALARCÓN IBARRA, J. (2003): Estudio del comportamiento de mezclas bituminosas recicladas en caliente en planta. Barcelona, Tesis Doctoral de la Universitat Politècnica de Catalunya. Escola Tècnica Superior d'Enginyers de Camins, Canals i Ports de Barcelona, dirigida por el prof. Félix Edmundo Pérez Jiménez. Disponible on-line en http://www. tdx.cat/handle/10803/5906 [Consultado el 1/09/12].

ALBA, R; MORENO GALLO, I. y RODRÍGUEZ, R. G. (Coord.) (2004): Elementos de ingeniería romana. Actas del I Congreso Europeo sobre «Las obras públicas romanas», celebrado en Tarragona entre los días 3 y 6 de noviembre de 2004. Tarragona. Colegio de Ingenieros Técnicos de Obras Públicas.

ARÍZAGA BULUMBURU, B. (1990): Urbanismo medieval. San Sebastián. Edit. Kriselu.

ARÍZAGA BULUMBURU, B. (1993): «El paisaje urbano en la Europa Medieval», en J. I. de la Iglesia Duarte (Coord.): Actas de la III Semana de Estudios Medievales. Recoge los contenidos de la Semana de Estudios Medievales de Nájera, celebradas en el 3 y 7 de agosto de 1992, Logroño, Instituto de Estudios Riojanos (IER), pp. 11-26.

BRANDIS GARCÍA, D. (2008): «La imagen cultural y turística de las ciudades españolas Patrimonio de la Humanidad», en M.A. Troitiño Vinuesa (Coord.): Ciudades Patrimonio de la Humanidad: patrimonio, turismo y recuperación urbana. Universidad Internacional de Andalucía y Consejería de Cultura de la Junta de Andalucía, Sevilla, pp. 70-97.

BRANDIS GARCÍA, D. y CANOSA, E. (2009): «Tiempo, espacio y forma para comprender la ciudad», en C. Delgado Viñas et al. (Coords.): Historiografía sobre tipos y características históricas, artísticas y geográficas de las ciudades y pueblos de España. Ediciones TGD, Santander (España), pp. 87-92.

BRANDIS GARCÍA, D. (2010): «Las imágenes del paisaje como valor cultural del patrimonio urbano», en M.A. Troitiño Vinuesa et al. (Coords.): Dinámicas funcionales del turismo y sus impactos en las ciudades Patrimonio de la Humanidad: estudios comparados entre México y España, Universidad de Guanajuato (México), Guanajuato, pp. 55-72.

BRANDIS GARCÍA, D. y RÍO LAFUENTE, M.I. del (2006): «Las imágenes de la ciudad histórica y el turismo», en N. Ortega Cantero (Coord.): Imágenes del paisaje. Servicio de Publicaciones de la Universidad Autónoma de Madrid, Madrid, pp. 199-227.

CALVINO, I. (1994): Ermitaño en París. Madrid. Ediciones Siruela. 
CAMPENSINO FERNÁNDEZ, A.J. (2001): «Las nuevas posibilidades económicas del Centro Histórico», en J. M. Iglesias Gil (Edit.): Cursos sobre el Patrimonio Histórico. Actas de los XI Cursos Monográficos sobre el Patrimonio Histórico (Reinosa, julio de 2000). Reinosa, Servicio de Publicaciones de la Universidad de Cantabria y Ayuntamiento de Reinosa.

CASTILLA DEL PINO, C. (2004): La Casa del Olivo. Autobiografía (1942-2003). Barcelona, Tusquets Editores.

COMPAÑÍA PENINSULAR DE ASFALTOS (1930): La loseta de asfalto comprimido C.P.A: usos y propiedades. Madrid, Edit. Compañía Peninsular de Asfaltos. Esta publicación, con 34 páginas de extensión, presenta una excelente colección fotográfica de calles de ciudades españolas que a finales de los años veinte habían remozado sus pavimentos introduciendo las losetas de asfalto comprimido.

CORRAL, C. (1992): «Movilidad, calidad ambiental y espacio público en los Centros Históricos», en Congreso Internacional de Urbanismo y Conservación de Ciudades Patrimonio de la Humanidad. Cáceres.

CORRAL, C. (1998): «Accesibilidad y movilidad en los centros históricos», en M. A. Troitiño Vinuesa y J. S. García Marchante (Coords.): Las ciudades históricas: recuperación integrada y dinámica funcional. Ediciones de la Universidad de Castilla-La Mancha y Fundación «La Caixa», Cuenca.

CORREYO RUIZ, B. y CAL, R. (2008): Turismo: la mayor propaganda de Estado. España, desde los orígenes hasta 1951. Madrid, Edit. Visión Net.

CULLEN, G. (1974): El paisaje urbano. Tratado de estética urbanística. Barcelona. Edit. Blume y Edit. Labor.

DIEGO GARCÍA, E. de (1996): Historia de la industria española. La química. Madrid. Actas Editorial y Escuela de Organización Industrial.

ESCOBAR ÁNGEL, J.F. (2000): De la ciudad y su espacio público. Manizales (Colombia), Universidad Nacional de Colombia (Sede Manizales).

ESCOBAR CAMACHO, J.M. (1989): Córdoba en la Baja Edad Medina. Evolución urbana de la ciudad. Caja Provincial de Ahorros de Córdoba, Córdoba.

ELSAN-PACSA (2003): Las vías urbanas. Parte I: los firmes urbanos. Monografía $\mathrm{n}^{\circ} 2$, Diciembre de 2003. Madrid. Editado por ELSAN-PACSA.

FRANCALACCI DA SILVA, B. (2010): Evaluación del impacto ambiental de los pavimentos urbanos exteriores. TFM del Máster en Arquitectura, Energia i Medi Ambient de la Universitat Politècnica de Catalunya. Dirección a cargo del Prof. Jaume Avellaneda DíazGrande.

GARCÍA GARCÍA, A., OJEDA RIVERA, J.F. y TORRES GUTIÉRREZ, F.J. (2008): «Hacia una nueva lectura de las ciudades y sus espacios: ausencias y emergencias en la ciudad inteligente», en A. García García (Coord.): Espacios públicos, ciudades y conjuntos históricos. Sevilla, Instituto Andaluz de Patrimonio (IAPH), pp. 145-161.

GARCÍA VERDUGO, F. R. (1986): «Las propuestas de ensanche en la ciudad de Córdoba», Estudios Geográficos, no. 182-183, pp. 149-172.

GARCÍA VERDUGO, F.R. (1992): Córdoba, burguesía y urbanismo. Producción y propiedad de suelo urbano: el sector de Gran Capitán, 1859-1936. Córdoba. Ayuntamiento de Córdoba. 
GONZÁLEZ BERNÁLDEZ, F. (1981): Ecología y paisaje. Madrid. Edit. Blume.

HALL, P. (1996): Ciudades del mañana. Historia del urbanismo en el siglo XX. Barcelona, Ediciones del Serbal, S. A., Colección «La Estrella Polar».

HERCE VALLEJO, M. (2009): Sobre la movilidad en la ciudad. Propuestas para recuperar un derecho ciudadano. Barcelona, Editorial Reverté, S. A.

HERCE VALLEJO, M. y MIRÓ FARRERONS, J. (2002): El Soporte infraestructural de la ciudad. Barcelona, Ediciones de la Universitat Politècnica de Catalunya, S. L.

HEERS, J. (1990): La ville au Moyen Âge. Paris. Edit. Fayard.

JACOBS, A. B. (1996): Grandes calles. Primera edición en inglés de 1993. Traducción a cargo del Gabinete de Traducción Babel (Santander). Santander. Servicio de Publicaciones de la Universidad de Cantabria y Colegio de Ingeniero de Camino, Canales y Puertos de Madrid.

LÓPEZ ONTIVEROS, A. (1981): Evolución urbana de Córdoba y de los pueblos campiñeses. Córdoba, Publicaciones de la Excma. Diputación Provincial de Córdoba, $2^{\text {a }}$ Edic.

LLAMAZARES GÓMEZ, O. (1963): «El empleo del alquitrán en los pavimentos de carreteras», Revista de Obras Públicas, noviembre de 1963, pp. 713-719.

MARTÍN LÓPEZ, C. (1986): «La creación de un centro urbano en la ciudad de Córdoba: la plaza de Las Tendillas», en Estudios Geográficos, nº. 182-183, pp. 119-147.

MARTÍN LÓPEZ, C. (1990): Córdoba en el siglo XIX. Modernización de una trama histórica. Córdoba. Ayuntamiento de Córdoba.

MORENO GALLO, I. (2004): Vías romanas: ingeniería y técnicas constructivas. Madrid. Ministerio de Fomento, CEHOPU.

MORENO GALLO, I. (2008): «Las obras públicas en la ciudad romana». Actas del IV Congreso de las Obras Públicas en la ciudad romana, celebrado en Lugo entre los días 6 y 8 de noviembre de 2008. Madrid, Colegio de Ingenieros Técnicos de Obras Públicas, pp. 33-56.

MORENO GALLO, I. (2010): «Las técnicas en la ingeniería romana». Actas del V Congreso de Obras Públicas Romanas, celebrado en Córdoba entre los días 7 al 9 de octubre d2 2010. Madrid. Fundación de la Ingeniería Técnica de Obras Públicas, pp. 78-92.

MORRIS, A. E. J. (1998): Historia de la forma urbana. Desde sus orígenes hasta la Revolución Industrial. Barcelona, Editorial Gustavo Gili.

MULERO MENDIGORRI, A. (1991): La población de Córdoba y sus barrios. Estructura y distribución recientes. Córdoba. Servicio de Publicaciones de la Universidad de Córdoba.

NARANJO RAMÍREZ, J. y LÓPEZ ONTIVEROS, A. (2011a): «Representación simbólica e imagen urbana de la plaza de «La Corredera» (Córdoba) a lo largo de su historia», en Boletín de la Asociación de Geógrafos Españoles, nº. 51, pp. 343-373.

NARANJO RAMÍREZ, J. y LÓPEZ ONTIVEROS, A. (2011b): La plaza de La Corredera de Córdoba. Funciones, significado e imagen a través de los siglos. Córdoba. Servicio de Publicaciones de la Universidad de Córdoba.

PASSINI, I. (1984): Villes Médiévales du chemin de Saint Jacques de Compostelle: de Pampelune a Burgos. Paris. Edit. Recherche sur les Civilisations.

PEINADO MARGALEF, N. (2011): «Diseño de espacios públicos: zonas de tránsito peatonal», en R. López Maldonado (Dir.): Guía para la utilización de pavimentos en espacios públicos. I Jornadas de diseño de pavimentos accesibles. Málaga. Ayuntamiento y Gerencia Municipal de Urbanismo de Málaga, pp. 15-26. 
RAMA LABRADOR, F. (2005): Estudio sobre la conservación de pavimentos urbanos y de sus deterioros. Valencia. Ed. Rama Labrador.

RAMA LABRADOR, F. (2006): «Historia de los pavimentos urbanos», Cimbra, no 371. Septiembre-Octubre de 2006, pp. 38-48.

SALAS MOZOS, E. y ALONSO LÓPEZ, F. (2005): La accesibilidad universal en los municipios: guía para una política integral de promoción y gestión. Equipo ACCEPLAN, Instituto Universitario de Estudios Europeos de la Universidad Autónoma de Barcelona.

SANTOS JENER, S. de los (1944 y 1945): «Zona de excavaciones en la calle de Cruz Conde», Memorias de los Museos Arqueológicos Provinciales. 